International Journal of Linguistics, Literature and Translation (IJLLT)

ISSN: 2617-0299 (Online); ISSN: 2708-0099 (Print)

DOI: $10.32996 / \mathrm{jjllt}$

Journal Homepage: www.al-kindipublisher.com/index.php/ijllt

\title{
Theoretical Aspects in Spanish>English Translation for University Students: Monitoring Teaching Tools and Further Suggestions for Translation Students
}

Francisco Godoy Tena

Department of English Philology, Faculty of Arts and Humanities, Universidad Autónoma de Madrid, Spain

Corresponding Author: Francisco Godoy Tena, E-mail: f.godoy@uam.es

ARTICLE INFORMATION ABSTRACT

Received: November 08, 2020

Accepted: December 19, 2020

Volume: 3

Issue: 12

DOI: $10.32996 /$ ijllt.2020.3.12.10

\section{KEYWORDS}

General Translation, teaching methods, translation tools, topic websites, glossary links
Spanish>English Translation for Spanish students is one of the most challenging subjects for non-native English translators. Thanks to these subjects, university students have a practical possibility to translate texts from several general and specialised topics. Owing to this fact, every theoretical study is important in other to reach optimal results in these practical courses. Unfortunately, the COVID19 outbreak at the end of the year 2019 and its subsequent worldwide spread has brought additional adaptations to our university studies. The aim of this study is to explain how these adaptations were introduced in our practical subject "Traducción General C2. Inglés" (General Translation C2. English), which focuses on Spanish>English Translation, and taught in the third course of Translation and Interpreting studies at the Universidad Autónoma de Madrid, Spain. In addition to this, this research includes some translation methods and conclusions observed during the course: analysis of Translation Cards of every text included in the subject, how the students mentioned problems and comments of every text, and how these problems can be corrected in the subject by considering every feedback from students and teachers. This final objective can, therefore, bring to light essential aspects coming from both sides of the translation teaching process in our universities.

\section{Introduction}

Teaching Spanish>English Translation constitutes a challenging experience at the university level for non-native English translators. The aim of this paper is to establish some parameters to Spanish students at the university in order to promote their individual motivation and work in their translation process.

This research has been addressed to "Traducción General C2" (General Translation C2), a university subject in the third course of the Translation and Interpreting degree at Universidad Autónoma, Madrid, Spain. This means their level might be slightly lower than their language $B$, so the choice of the translation pack should be initially considered in order not to provide them with difficult texts. However, this should not be an obstacle to suggest several texts from different general translation documents. The practical and challenging process of translating these texts may be a learning path for future translators.

\section{Literature Review}

There are several works that deal with the teaching process of Translation, so this study includes some of the studies of this important discipline. In late $20^{\text {th }}$-century we have works by Newmark (1988), who explained 8 methods of Translation, based on the source language, and he gave prominence to accuracy and economy, Hatim and Mason $(1990,1997)$ and their theory of Translation or Kussmaul (1995) and the students' mental activity in their process of translation, among many others.

Additionally, we may mention several researchers of translation teaching tools, such as Borja (2007) and her detailed compilation of materials for Legal Translation or Niño (2009), whose research analysed the Machine Translation.

K C AL-KINDI CENTER

$\mathbf{R}$ D FOR RESEARCHA

Your gateway to world-closs research
Published by Al-KindiCenter for Research and Development. Copyright (c) the author(s). This is an open access article under CC BY license (https://creativecommons.org/licenses/by/4.0/) 
We could also mention works by Vermes (2010) and his overview of the pros and cons of translating in class, Zainudin and Mat Awan (2012), who worked on wrong translation techniques from Malay into English, Li (2013), who focused his research from teaching to learning, drew students' attention to the translation process, developed practices, and activated and developed translation competence.

Márquez and Solís-Becerra (2013) explored the process of Translation from the $19^{\text {th }}$ century to the present time in secondary education in Murcia, a southeast region of Spain. Additionally, we may add Al-Musawi (2014), who studied the translation process of undergraduate students in Bahrein by following strategies, such as the enhancement and development of their reading and writing skills.

More recently, there are several translation studies, such as Soang (2016), who investigated the problems of Taiwanese students when translating Spanish advertisements into English. Vázquez y del Árbol's extensive work (2014a, 2014b, 2016) includes a deep knowledge of Legal and Science Translations, among other disciplines. She includes source and target texts with an additional explanation to translation students in order to describe the translation options in each text. This is completed with a theorical part at the beginning of her books and a very useful glossary at the end of every text.

Gorozhanov et al. (2018) pointed out the importance of virtual practice and how students work in an online environment to improve their translations. In this case they analysed the bilingual studies (English $>$ Russian) by using tutorials of translation mistakes and discussing the difficulties of the text. This study highlights the misuse of translation techniques, such as the word-for-word translations as well as the lack of an appropriate use of a term in a translation.

To conclude, recent studies are Liu and Yu (2019), researchers of Master of Translation and Interpreting (MTI) studies and how translators are motivated by monitoring one MTI student, Vázquez y del Árbol and Godoy (2019) implemented a translation card for scientific and technical translation students with positive results in their feedbacks.

\section{Methodology and Material}

During the course all my translation students have been provided with the following materials:

1. Two packs of texts: one was named as "Block A: Humanities", while the other was labelled as "Block B: Science".

2. A Translation Card template.

3. Sight Translations (with topics in Blocks A and B) to work in class.

4. Website links for all the topics in the course.

\subsection{Translation Pack}

Both have some texts that students need to translate during our course. These texts increase in difficulty as we continue our translation process. Here we can mention the textual genres included in both blocks:

\begin{tabular}{|c|c|}
\hline Block A: Humanities & Block B: Science \\
\hline - $\quad$ Text 0 "starter" & - Text 6 "Cancer" \\
\hline - Text 1 "leaflet" & - Text 7 "Biology" \\
\hline - $\quad$ Text 2 "education" & - Text 8 "Health" \\
\hline - Text 3 "travel” & - Text 9 "Technology" \\
\hline - $\quad$ Text 4 "art and history" & - Text 10 "Finance" \\
\hline - Text 5 "humanities and science" & \\
\hline
\end{tabular}

Block A started with an easy text (text 0) to translate from Spanish into English. The main reason was to establish a common base so that everyone could initially begin the course without many translation problems. This block increased its level of difficulty as the students made progress in their translations from the initial text to the last document (Text 5), which had a hybrid text of both blocks: arts and humanity and science. 
Block B, dealing with scientific texts, was slightly more difficult and challenging for our students. The first three texts (texts 6 to 8) were semidivulgative documents that introduce them in a more specialised translation scene. These first three texts included specific terminology, but the level of complexity was lower than most of the texts related to these topics. The two texts (texts 9 and 10) had more complexity in their terminology and syntax.

\subsection{Translation Card}

Owing to the COVID19 pandemic, our university decided to split all classes into two groups, so that one works in class while the other translate the packs at home. Therefore, we had to adapt our teaching methods to this unavoidable circumstance.

In this case it was decided to create a Translation Card that every student had to do while working at home. This template had the next questions they needed to complete at home:

\begin{tabular}{|l} 
TRANSLATION CARD \\
TRANSLATOR_ \\
TEXT NO. Please give 4 / 5 lines, features, problems (...) in each (in English) \\
- How did you find the text? \\
- What lexical features / problems did you find in it? \\
- How did you solve those problems? \\
- Websites, dictionaries, glossaries ... used in the translation process \\
- Could you have some further comments?
\end{tabular}

\subsection{Sight Translation}

While half of the group worked at home, the other students corrected the texts in class. They had they feedback and my corrected version, pointing out some possible options, uses of collocations and common mistakes in terminology, syntax, style and punctuation.

Sight translations were translated with my class students. As they were previously provided with a document with some online dictionaries, they were requested to work with them in our class. I checked what online dictionaries they visited and recommended to use several translation tools in their translation process. The following summarized lists may help Translation and Interpreting students in their studies.

A. Monolingual and bilingual dictionaries

Monolingual and bilingual dictionaries were the first tools taught in class. Owing to the different types of "Englishes" worldwide, the list included dictionaries from several English-speaking countries, such as the United Kingdom, the United States, South Africa, Australia or Canada. Some of the tools are:

- http://dictionary.cambridge.org/es/diccionario/ingles-espanol/

- http://www.wordreference.com/es/

- http://diccionario.reverso.net/ingles-espanol/

- http://www.larousse.com/es/diccionarios/ingles-espanol

- $\quad h t t p: / / w w w . l i n g u e e . e s /$

- https://www.collinsdictionary.com/es/ 
- https://en.oxforddictionaries.com/

- http://blog.tesol.org/6-online-dictionaries-for-english-learners/

- http://diccionario.babylon-software.com/ingles/ingles/

- http://es.pons.com/traducci\%C3\%B3n/espa\%C3\%B1ol-ing|\%C3\%A9s

- https://www.merriam-webster.com/

- https://www.australiandictionary.org/

- https://dsae.co.za/

- https://www.uottawa.ca/language-services/online-tools-and-resources

B. Specialised Dictionaries

Students were provided with an exhaustive list of dictionaries, glossaries and websites to work both blocks. Here you may find some samples of online dictionaries from Block $A$ :

- [Text 3] Travel: https://www.trekksoft.com/en/tourism-glossary/

- [Text 4] Art: http://www.artcyclopedia.com/

- [Text 4] History: https://www.historyonthenet.com/historical-dictionary

In Block B we may mention the following examples:

- [Text 6] Medicine: https://medical-dictionary.thefreedictionary.com/

- [Text 7] Biology: https://www.biologyonline.com/dictionary

- [Text 10] Finance: http://www.spanish-translator-services.com/espanol/diccionarios/finanzas-espanol-ingles/

C. Dictionaries of synonyms and collocations

Collocations are important aspects to consider in the whole process of translation. We may include some online dictionaries, such as:

- https://www.thesaurus.com/

- http://www.freecollocation.com/

- https://www.oxfordlearnersdictionaries.com/definition/collocations/

- http://www.ozdic.com/

\subsection{Links provided}

As it was mentioned above, a 6-page document was prepared and sent to all the students so that they could have several links of glossaries and websites to work individually. This was challenging, as the topics were wide to manage in some websites, so it was decided to suggest general websites from those topics, so that they could find parallel texts in English and help them identify recurrent phraseology. Additionally, more glossary pages were added in order to have a more specific idea of those topics.

These websites were divided according to their topics. This can be observed in the examples (from Blocks A and B) below chosen from a more extended list:

- Education

https://global.oup.com/education/help/glossary/?region=international

http://www.gostudyuk.com/glossary/ 
http://www.doe.virginia.gov/glossaries/index.shtml

- $\quad$ Art

https://www.moma.org/learn/moma_learning/glossary/

http://www.arthistoryarchive.com/arthistory/glossary/Art-Glossary-Terms-AA-AZ.html

https://architecturaltrust.org/outreach/education/glossary-of-architectural-terms/

- Biology

http://www.phschool.com/science/biology_place/glossary/

https://biologydictionary.net/complete-list-biology-terms/

https://biologywise.com/biology-glossary-of-terms-definitions

- Computing

https://www.angelo.edu/services/technology/it_policies/glossary.php

https://www.dpsolutions.com/success-center/it-terminology-glossary

\section{Results and Discussion}

Once the Translation Cards were collected, they were analysed in order to see some common problems and observations in their comments. Thanks to this feedback, we could observe some findings:

All the students included their comments in their Translation Cards. They are summarised as follows:

\subsection{Lexical aspects}

- Use of pages explained before, such as Thesaurus, dictionary of collocations, several online dictionaries, such as Merriam Webster, Collins, some of them monolingual. This was a positive result in some of the students who, thanks to the submission of online dictionaries and websites, they could widen their translation tools they may find on the internet.

This was possible in some of their comments, when a student suggested her option once she had previously looked several terms up on the online Merriam Webster dictionary. She chose the best option thanks to this and she pointed out the importance of monolingual dictionaries in order to catch the real meaning of the term.

- There were some comments about how to translate specific terminology included in the texts, such as "DELE" [Diploma of Spanish as a foreign language] [text 2: education]. Students also mentioned the complexity of text 10 (Finance), where they had to deal with unknown terminology. Some of them commented that, thanks to this text, they improved in their knowledge of this specific topic.

- Students had other basic problems in terminology. This is the case of the Spanish word "chimenea", which had two equivalences in the same target text: "chimney" and "fireplace" [text 0]. However, most of the students had the wrong option in the text. They also found problems in "crías", translated as "young" instead of "offsprings" [text 7], "alimento" (wrongly translated as "ailment" instead of "food") or "refrescos light" (as "light soft drinks, instead of "diet soft drinks") [text 8].

- They had a frequent problem to omit measure conversions, as most of the students did not convert these measures in their target texts. This was the case of litres into gallons [text 1]. However, once the text was corrected in class, they included the correct measure in the following texts, such as the Spanish term "gramos" into the English word "ounces" (oz.) [text 8] or euros into dollars or pounds (depending on the final client) [text 9], among others.

- Use of idiomatic expressions that could not be translated literally. This is the case of "a simple vista" (text 2: education), translated as "to a naked eye" by means of a coined equivalence. These idiomatic expressions also appear in other texts, such as "flipar en colores" ("flip out, to be flabbergasted..." [text 4]) or "mercado bajista" ("bearish market") [text 10]. 
- They mention the possible English varieties in some of the texts (US and Uk varieties, mainly). This is the case of lexical varieties, such as "grifo" in Spanish ("tap" in the British variety, "faucet" in the American variety) [text 1], spelling changes ("gris azulado": "bluish grey" in British English or "bluish gray" in American English) [text 9].

They showed other concerns, such as the repetitive use of terminology in some texts. Students included this fact, and how they solved this problem and they included their concern about how to avoid terminology repetition.

\subsection{Syntactical aspects}

- There was an increase in the comments of the difficulties as the course progressed (more obvious at the end of Block $A$ with the art and history text). Lexical and syntactical levels. At this point they found websites more useful. They observed the more complexity use of sentences in the last texts of Block A.

- Many comments were aware of their own literal translations, so they showed their concern about how to translate some syntactical sentences. Some of the students reorganized the sentence structure in order to sound less literal and more adapted to the target language.

Finally, it should be pointed out other orthotypographical problems, such as the misuse of commas in the sentence, use of longer sentences and their incorrect use of punctuation in hyphens or thousand and decimal numbers [texts 9 and 10].

Owing to all these observations, it was imperative to tackle with the problems observed in the first part of the subject, which corresponds to Block A. Some of them were imperative, such as the wrong understanding of translating techniques or some syntactical problems. Owing to this reason, the first class after my translation card corrections was devoted to an explanation of the translation techniques and other mistakes observed in the translations.

\subsection{Problems in the students' Translation Cards}

- An increasing level of difficulty of the texts should be planned in the course. This was previously considered in this year's pack of texts, so many students included this observation in their comments.

- Students should be monitored in class. It was noticeable the fact that most of them looked for the same online dictionaries, so they need to be motivated to use other translation resources in order to widen their translation research.

- The use of sight translations in class may help them identify their translation path and how they may be redirected to several tools.

- Some students had problems in their explanation of the translation techniques, such as "Transposition" (also called "Shift" or "categorization"). All the translation techniques were reviewed in both subgroups in order to clarify misunderstandings in the name and use of those techniques.

- Additionally, some others did not fill in the Translation Cards with enough information. They were informed once all their Translation Cards were collected, so the second block were more complete.

- On the other hand, other students included their own translation process, with their own personal opinions (Am I translating correctly?). Owing to this reason, their critical participation in class has been highly recommended during the course and they were encouraged to mention their opinions and all the translation techniques used while translating.

\section{Conclusions}

Undoubtfully, Spanish>English Translation is a challenging experience for students with English as their third language, especially under difficult circumstances like the worldwide pandemic COVID19. However, we should encourage our students, make them feel more confident and independent when translating texts dealing with different topics. Students were at first reluctant to using other online dictionaries that were not in their "comfort zone". Owing to this fact, a direct contact with them and an individual monitoring when possible are highly advisable when dealing with this limited use of resource tools.

This process is demanding and with many aspects to consider: this study showed that students are familiarised with some tools and the translation process from A to B. However, as they faced with a deeper analysis of the texts, either at home with their Translation Cards or in class with our translation discussion, they realised that there exist other variables in this translation process:

- Importance of idiomatic expressions and collocations in both source and target texts. 
- Use of translation techniques in their translation process.

- Students should understand the importance of having several translation tools that could help them in their translation process.

- Importance of lexical, syntactical and punctuation distinction in both languages.

- Conversion of liquid, weight, length or temperature measures into the target text and audience.

- $\quad$ Choice of several English varieties in terminology and spelling, depending on the client.

This study has obviously implied some limitations, as teachers may not have the possibility to monitor continuously the students' translation process. However, this limitation of time and space may be corrected with a continuous control in the Translation Cards done at home, sight translations and opinions voiced in class. Therefore, this practical research could be implemented in every translation class, and its results can bring further implications in future Translation studies, especially in exceptional circumstances, such as the COVID19 pandemic. This situation requires many implemented tools to control their mistakes and to offer solutions to their problems.

Funding: This research received no external funding.

Conflicts of Interest: The authors declare no conflict of interest.

\section{Reference}

[1] Al-Musawi, N. (2014). Strategic Use of Translation in Learning English as a Foreign Language (EFL) among Bahrain University Students. Comprehensive Psychology, 3, 1-10. https://doi.org/ 10.2466/10.03.it.3.4.

[2] Borja Albi, A. (2007). Estrategias, materiales y recursos para la traducción jurídica inglés-español. Publicaciones de la Universitat Jaume. [3] Gorozhanov, A. I., Kosichenko, E. F., and Guseynova, I. A. (2018). Teaching Written Translation Online: Theoretical Model, Software Development, Interim Results. SHS Web of Conferences 50, 1- 6. http://doi.org/ 10.1051/shsconf/20185001062.

[4] Hatim, B. and Mason, I. (1990). Discourse and the translator. Longman.

[5] Hatim, B. and Mason, I. (1997). The Translator as Communicator. Routledge.

[6] Kussmaul, P. (1995). Training the Translator. John Benjamins.

[7] Liu, C., Yu, C. (2019). Understanding students' motivation in translation learning: a case study from the self-concept perspective. AsianPacific Journal of Second and Foreign Language Education, 4, 4. https://doi.org/10.1186/s40862-019-0066-6

[8] Li, D. (2013). Teaching Business Translation. The Interpreter and Translator Trainer, 7, 1-26.

https://doi.org/10.1080/13556509.2013.10798841.

[9] Newmark, P. (1988). A Textbook of Translation. Prentice Hall.

[10] Niño, A. (2009). Machine Translation in Foreign Language Learning: Language learners' and Tutors' Perceptions of its Advantages and Disadvantages. ReCALL, 21(2), 241-258. https://doi.org/10.1017/S0958344009000172.

[11] Soang, L.L. (2016) Translation Teaching: The Importance of Translator's Native Language. Open Journal of Modern Linguistics, 6, 247254. https://doi.org/10.4236/ojml.2016.64027.

[12] Marqués Aguado, T., Solís-Becerra, J. A. (2013). An overview of translation in language teaching methods: implications for EFL in secondary education in the region of Murcia. Revista de Lingüística y Lenguas Aplicadas, 8, 38-48. https://doi.org/10.4995/rlyla.2013.1161. [13] Vázquez y del Árbol, E. (2014a). Los actos procesales: estudio macroestructural contrastivo (inglés-español) aplicado a la traducción. Fachsprache 3-4. 179-204. https://doi.org/10.24989/fs.v36i3-4.1391.

[14] Vázquez y del Árbol, E. (2014b). Derecho Civil Comparado aplicado a la Traducción Jurídico-Judicial (Reino Unido y España). Dykinson. [15] Vázquez y del Árbol, E. (2016). Traducción judicial y policial (Inglés <> Español) y Derecho Comparado. Dykinson.

[16] Vázquez y del Árbol, E. and Godoy Tena, F. (2019). La IMPLANTAción de la Innovación Docente en el Aula de Traducción Especializada". Proyecto de Innovación Docente (Modalidad Implanta). Facultad de Filosofía y Letras. Grado de Traducción e Interpretación. Universidad Autónoma de Madrid, Spain.

[17] Vermes, A. (2010). Translation in Foreign Language Teaching: A Brief Overview of Pros and Cons. Eger Journal of English Studies X, 8393.

[18] Zainudin, I. S. and Mat Awan, N. (2012). Teaching Translation Techniques in a University Setting: Problems and Solutions. Procedia Social and Behavioral Sciences 46, 800 -804. https://doi.org/10.1016/j.sbspro.2012.05.202. 